Abstracta Iranica

Revue bibliographique pour le domaine irano-aryen

Volume 32-33 | 2013

Comptes rendus des publications de 2009-2010

\title{
Carl W. Ernst. Accounts of Yogis in Arabic and Persian Historical and Travel Texts
}

\section{Fabrizio Speziale}

\section{(2) OpenEdition \\ 12 Journals}

\section{Édition électronique}

URL : http://journals.openedition.org/abstractairanica/40624

DOI : 10.4000/abstractairanica.40624

ISSN : 1961-960X

Éditeur :

CNRS (UMR 7528 Mondes iraniens et indiens), Éditions de l'IFRI

\section{Édition imprimée}

Date de publication : 1 décembre 2013

ISSN : 0240-8910

Référence électronique

Fabrizio Speziale, "Carl W. Ernst. Accounts of Yogis in Arabic and Persian Historical and Travel Texts », Abstracta Iranica [En ligne], Volume 32-33 | 2013, document 271, mis en ligne le 01 juillet 2016, consulté le 03 octobre 2020. URL : http://journals.openedition.org/abstractairanica/40624 ; DOI : https://doi.org/10.4000/abstractairanica.40624

Ce document a été généré automatiquement le 3 octobre 2020.

Tous droits réservés 


\title{
Carl W. Ernst. Accounts of Yogis in Arabic and Persian Historical and Travel Texts
}

\author{
Fabrizio Speziale
}

\section{RÉFÉRENCE}

Carl W. Ernst. « Accounts of Yogis in Arabic and Persian Historical and Travel Texts ». Jerusalem Studies in Arabic and Islam, vol. 33, 2008, p. 409-426.

1 Cet article analyse les descriptions des yogis hindous et de leur pratiques qui se retrouvent dans les textes historiques et les récits de voyage en arabe et en persan, ainsi que dans quelques ouvrages portant sur d'autres sujets, tel le traité persan de géographie Haft iqlìm (composé en 1594) d'Amīn b. Aḥmad Rāzī. L'A. se concentre en particulier sur les textes persans composés au cours de la première modernité, parmi lesquels on trouve des safar-nāma, le Baḥr al-asrār de Maḥmūd b. Amīr Walī BalH̄ī (XVII ${ }^{\mathrm{e}}$ s.) et le Tuhfat al-'ālam (1804) de Mīr 'Abd al-Laṭîf Hुān Šuštarī ; ainsi que des journaux officiels de l'empire moghol, tel le Hulāṣat al-tawārīH (composé en 1695-6) de Sujān Rāy Bhandārī. 


\section{AUTEURS}

\section{FABRIZIO SPEZIALE}

Université Sorbonne Nouvelle-Paris 3/Mondes iranien et indien, Paris 